good name had recently been used in the character assassination of Gottfried Leibniz, the German philosophical genius and protégé of the future King George I of Great Britain and Ireland. Isaac Newton himself had secretly masterminded the attack, personally embellishing the society's dossier about Leibniz's supposed plagiarism of the calculus during a visit to London in 1676. In this case, civility did not ensure morality, of any sort.

Shapin is completely aware of this dark side of science. His excellent bibliography lists the writings of many respected voices, such as Sheldon Krimsky in Science in the Private Interest, complaining about morally dubious practices in science. But their critical perspective never appears in his narrative. One would not know from reading The Scientific Life that Shapin has published many essays showing deep sympathy with those who offer such complaint. For example, he writes of Craig Venter, who has pioneered the creation of new life forms for private profit. He answers objections as they are raised, but the deeper issues of the safety and morality of Venter's enterprise are ignored.

Shapin's study is neither a sources-based history of the past nor an empirical socialscience analysis of the present. It is instead an extended insightful essay. This genre enriches public debate - be it by an academic, as in David Riesman's The Lonely Crowd or Robert Putnam's Bowling Alone, or the product of a distinguished journalist, such as James Fallows's classic National Defense. Through his many writings on science, Shapin has become one of these public intellectuals. But Shapin's book lacks a critical edge. It is as if he has been so seduced by civility, ancient and modern, that he has devoted his great talents to extolling its virtues.

For a scholar of Shapin's stature, it is inappropriate simply to say that he has forgotten his own critical awareness. He is serious in his use of ethically charged terms. I see this controversial element as a symptom of an unresolved problem in a bigger endeavour: those who promoted the organization of societies around objective scientific rationality, such as Weber, were not talking merely about more education and more knowledge. In the Enlightenment movement that flourished through the eighteenth and nineteenth centuries, science was seen as the main weapon against the obscurantism that drew on dogma and superstition. Impersonal science was therefore seen as the key to both real knowledge and a good society. In the intervening period, that early vision of science has been badly damaged. Today, public distrust has become widespread.

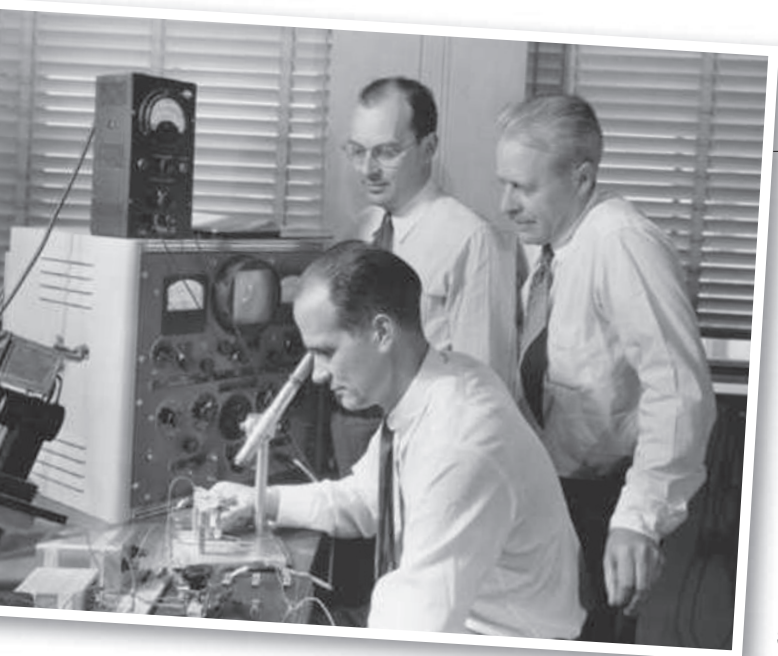

Disagreements between transistor inventors William Shockley (seated), John Bardeen (left) and Walter Brattain ended their fruitful collaboration.

Shapin, however, believes that in today's industrialized science, the politeness and civility of pre-modern communities persist. They are essential, he thinks, because of the uncertainties that beset this science. In rapidly moving fields such as synthetic biology, scientists must rely heavily on each others' virtue. In that way, for him, even scientific entrepreneurs are ual moral virtues. Yet we now know that the collective endeavour of these other very nice entrepreneurial scientists has resulted in the creation of a mountain of toxic fake securities. A sobering thought.

Jerome Ravetz is associate fellow at the James Martin Institute for Science and Civilization at the University of Oxford, Oxford OX11HP, UK. $\mathrm{He}$ is author of Scientific Knowledge and Its Social Problems.

e-mail: jerome-ravetz@tiscali.co.uk

\title{
Natural selection and the nation
}

Banquet at Delmonico's: Great Minds, the
Gilded Age, and the Triumph of Evolution in
America
by Barry Werth
Random House: 2009.400 pp. $\$ 27$

"There is apparently much truth in the belief that the wonderful progress of the United States, as well as the character of the people, are the results of natural selection," wrote Charles Darwin in The Descent of Man. Today, such a claim jars, and not just because of the grammar. But the wonder is that Darwin so infrequently over-extended his evolutionary explanations.

Not so his English contemporary, Herbert Spencer, who attempted to give an evolutionary account of almost every realm of human affairs. Ruminating on history, psychology, sociology and ethics, Spencer's evolutionary philosophy led him to argue that, among other things, government regulation was bad, the poor and needy should be left to fend for themselves, and the United States was destined to become the pinnacle of civilization. These ideas fell on fertile ground, particularly in the United States, and Spencer was hailed there as the brightest, most insightful man of his generation.

Banquet at Delmonico's, titled after an 1882 dinner to honour Spencer at a New York restaurant, covers the elite's battle for ideas during the turbulent years of the 1870 s and 1880 s. The nation was emerging from a bitter civil war that had led many to question the benevolence of God. It was obvious that the country was about to transform itself from an underpopulated minor player to a worlddominating industrial giant, and its direction and politics were up for grabs. The issues of the times were challenging: credit crunches, presidential unpopularity, disputed elections, terrorist atrocities, military blunders, and arguments about the nature of marriage, race relations and intelligent design. Manhattan got electrical lighting, Pittsburgh got steel and General Custer got annihilated.

Spencer's US acolytes included powerful industrialists, politicians, religious leaders and intellectuals. In a beautifully written classic of non-fiction narrative, author Barry Werth tracks Spencer and associated characters as they try to use evolutionary doctrine to perfect humankind and society, often attempting to take the credit. The startling cast includes the liberal Christian minister and alleged adulterer Henry Ward Beecher, the first female candidate for US president, Victoria Woodhull, and the publisher and self-flagellating scientific crusader Edward Youmans. Among the academics are Harvard University's John Fiske, who believed in the country's divine destiny, Louis Agassiz, who believed human races were 
created separately, and Asa Gray, who believed fervently in both Darwin and Christianity. The book is so rich in details - church meetings, fossil hunts, ocean voyages, hikes, courtroom dramas and Victorian hypocrisy - that it reads like a novel. But the narrative drive is weak: it is often hard to see where the story is going or why. That, I guess, is reality.

It is also not obvious why the book culminates with much hyperbole in the eponymous banquet. This 12-course meal, with a separate wine for each course, was held at a famous Manhattan restaurant shortly after Darwin's death. It was attended by 200 of the most powerful men in the United States, and celebrated Spencer at the end of what was to be his last US trip. The build-up to the meal is tremendous, and we are treated to all the procedural details - course three of the first service included buttery, scarlet kettle-drum-shaped pastry tufts stuffed with truffles, tongue and pistachios - and there is a very full summary of the three hours of afterdinner speeches. The book's cover claims that this event was "a historic celebration from which the repercussions still ripple throughout our society". But I now understand why I had never heard of it. Spencer himself found the speeches boring and wanted to leave early. The audience found a new idea only in John Fiske's speech: he asserted that humans acquired a sense of morality not from God, but from natural selection. The only speech that might

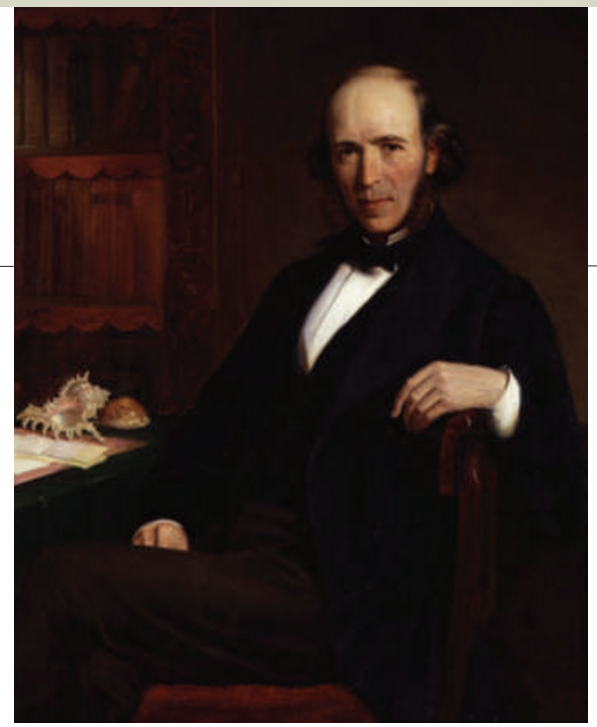

Herbert Spencer felt evolution could cure social ills.

resonate today was Spencer's own. Worried about the country's well-being and health, he railed against the national work ethic, arguing that Americans should spend less time striving for a future good, and more time enjoying what the passing day had to offer. The idea baffled his audience and was poorly received.

Yet the narrative non-fiction genre allows unexpected things to emerge. Many of the protagonists were, like Darwin, bedevilled by bad health. Doctors are summoned at a frightening rate throughout the book. The ailments were many and the treatments fascinating - at one point, Agassiz was forbidden from thinking. That natural selection should have excised such sick men does not seem to have caused much concern among any of these social Darwinists. Moreover, neither Spencer nor any of his US disciples seems to have spent any time trying to push evolution into medicine, even though medicine was becoming a serious scientific enterprise, with the verification of the germ theory of disease and the developing cellular theory of disease (now pathology). Even today, medicine is the most obvious area in which evolutionary biology remains under-extended. Mutation, competition and selection are key to understanding cancer and infectious diseases, for example, but still very few medical schools teach evolutionary biology.

We have yet to fully comprehend the consequences of what Darwin did to humanity's view of itself. Werth's picture of what his 'great minds of the gilded age' were thinking, of how far they tried to stretch Darwinian insights, and of the personal and moral lessons they drew, makes a forceful argument that the causes of biological diversity - and humankind's place within it - really matter. The fact that many of these thinkers' conclusions were based on such a poor understanding of evolution also shows why everyone deserves proper schooling in evolutionary biology. The Victorians had the crippling disadvantage that they did not understand inheritance or units of selection. Today, humanity has no such excuse.

Andrew F. Read is professor of biology and entomology at Pennsylvania State University, University Park, Pennsylvania 16802, USA. e-mail: a.read@psu.edu

\section{Portraying the embryo}

\section{Making Visible Embryos \\ by Tatjana Buklijas and Nick Hopwood Exhibition at http://tinyurl.com/9m8s7u}

"Do we not find a rosebud as beautiful in its own way as a rose?", mused the great German anatomist Samuel Thomas Sömmerring. He was defending his revolutionary work, published as a series of large-format plates in 1799, showing that embryos took different forms at different stages.

The story of how embryos have been depicted is the subject of the online exhibition Making Visible Embryos, by historians of science Tatjana Buklijas and Nick Hopwood.

Before Sömmerring, anatomists adhered to the Aristotelian theory that the individual adult was present in the germ cell, and simply grew in size - no rosebuds, just small, perfect roses. The debate was only whether the homunculus was encapsulated in the egg or the sperm. The concept of the embryo as an unformed blob did not fit with theories of the Creator's perfection.

Then experimentation took over. Human embryos were in short supply, but Sömmerring systematically acquired them from abortions, picked out the best examples, which he assumed to be less malformed, and drew his own conclusions.

The exhibition of more than 120 images, from engravings and wax models to $\mathrm{X}$-rays and ultrasound scans, presents how scientists have struggled to understand the embryo in its biological and moral contexts. We learn how Jesus was often depicted as a small but fully formed child in the womb of the Virgin in medieval and earlymodern paintings. We learn how German experimental zoologist Ernst Haeckel, one of Charles Darwin's most insistent propagandists, used his considerable

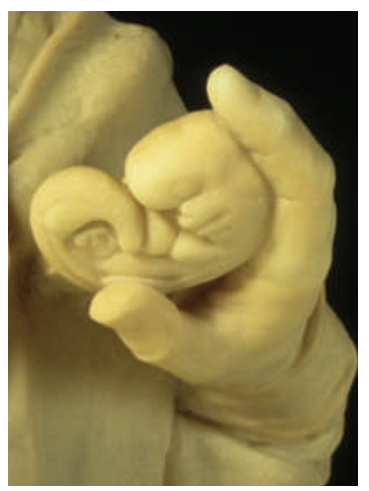

artistic skills to present images of developing embryos - and massaged some to support his theory that different species pass though similar embryonic stages. And we discover how the emotionally powerful images of Swedish photographer Lennart Nilsson were, ironically, taken from aborted fetuses. In the 1960s, these photographs influenced the modern public view of the fetus as a child waiting to be loved, and thus fuelled the fire of anti-abortionists.

The website is structured by theme; each section runs chronologically and information is provided at three levels of depth. This architecture mostly works well. But it is less suited to complex discussions, such as the nineteenthcentury scientific controversies over embryology, in which it is easy to lose track of the different players, their arguments and how it all fitted together. But the pictures speak volumes, even though images of the embryo are nowadays commonplace. Scientists initially struggled to Alison Abbott is Nature's senior
grasp how embryos develop. European correspondent. 